\title{
FLNA wt Allele
}

National Cancer Institute

\section{Source}

National Cancer Institute. FLNA wt Allele. NCI Thesaurus. Code C113586.

Human FLNA wild-type allele is located in the vicinity of Xq28 and is approximately $26 \mathrm{~kb}$ in length. This allele, which encodes filamin-A protein, plays a role in actin structure and function. Mutations in this gene are associated with several syndromes, including periventricular nodular heterotopias, otopalatodigital syndrome type 1 and type 2 , frontometaphyseal dysplasia, Melnick-Needles syndrome, and X-linked congenital idiopathic intestinal pseudoobstruction. 